RAD Conference Proceedings, vol. 4, pp. 118-120, 2020

ISSN 2466-4626 (online) | DOI: 10.21175/RadProc.2020.25

www.rad-proceedings.org

\title{
APPEARANCE OF SILICOSIS AND ASBESTOSIS IN DUST EXPOSED WORKERS
}

\author{
Elisaveta Petrova*
}

ACC Tokuda Medical Center, Acibadem City Clinic Tokuda Hospital, Sofia, Bulgaria

\begin{abstract}
The aim of the study was to predict the occurrence of silicosis and asbestosis, resp. from dry or from dry and water drilling in the mines among former miners, and among asbestos exposed workers by determining the duration of dust free period [DFP] - for silicosis, and latent period [LP] - for asbestosis, and to describe some new trends of appearance of early silicotic changes during water drilling in the Bulgarian mines. DFP was investigated among 481 quartz exposed miners, and the LP - among 120 asbestos exposed workers. A retrospective and cross-sectional study, using linear regression analysis for DFP, respectively nonparametric analysis - for mean of LP has been performed. SPSS software package has been used. The DFP has been calculated, using the formula: $Y=A+X 1 . B+X 2 . C+X 3 . D+$ $X 4 . E$, where the regression coefficients were: $A$ (free coefficient), $B$ (age), $C$ (dust exposure duration), $D$ (total dust concentrations), and $E$ (quartz presence in the dust). The coefficients have been of different values for each mine. The average LP up to the occurrence of benign asbestos diseases was about 17.45 years. Conclusions: Calculation of DFP and LP values, together with the knowledge of the number of exposed workers and their exposure makes possible to predict the occurrence of silicosis and benign asbestos diseases in future.
\end{abstract}

Key words: Silicosis, asbestosis, dust-free period, latency period, appearance

\section{INTRODUCTION}

The problems about silicosis appearance, the levels of the mineral dusts in the working environment, the duration of dust exposure, the dust free period (DFP) and latency period (LP) up to the occurrence of the collagen pneumoconioses [silicosis and asbestosis] were discussed in the world literature during decades $[1,2,3$, 4, 5, 6, 8 and 9].

The exposure to low quartz levels (1-2 mg/m3), which could result to late development of silicosis (5-15 years after ceasing dust exposure) has been found $[1,2$, 3]. At low quartz levels in the air in working environment, reticular or reticular - micro nodular silicosis could be developed. In these cases, the dose/effect relationship is dependent on the quartz concentration in the work environment [2], as well as the cumulative quartz exposure dose, presented as the sum of the dust concentration and the duration of dust exposure [1] and from duration of the quartz residence in the lungs $[1,2,3,4]$.

Some authors [5] predict that asbestos exposed workers could develop pulmonary fibrosis by exposure to asbestos fibers with a diameter of less than $2 \mu \mathrm{m}$ and a length of $10-50 \mu \mathrm{m}$. The asbestos-induced pulmonary fibrosis could increase the risk of lung cancer, as well as asbestos related mesothelioma when the diameter of asbestos fibers is less than $0.5 \mu \mathrm{m}$ and their length had varied from $5 \mu \mathrm{m}$ to $30 \mu \mathrm{m}$. Asbestos pleural plaques amongst population exposed to asbestos in areas with endemically asbestos contaminated soils after 30 years of latency period could be expected. Some authors predict $[1,6]$ that for the occurrence of malignant lung diseases (lung cancer, malignant pleural mesothelioma), the latency period have to be $20-40-50$ years.
In moderate asbestos exposure, the exposure duration must be from 5 up to 10 years (for lung carcinoma), resp.10 and more years (for malignant mesothelioma) [7].

In situation of extremely high asbestos concentrations in work environment air the risk of lung cancer is 2-fold higher [6].

Essential for the determining of the moment of occurrence of silicosis and asbestosis, are respectively the dust - free period $($ DFP $=$ the time from discontinuation of quartz exposure up to appearance of silicosis), and the latency period (LP $=$ the time from beginning of asbestos exposure up to the appearing of asbestosis).

\section{AIM}

The aim of the study was to predict the occurrence of silicosis and asbestosis, resp. from dry or from dry and water drilling in the mines among former miners, and among asbestos exposed workers by determining the duration of dust free period (DFP) - for silicosis, and latent period (LP) - for asbestosis, and to describe some new trends of appearance of early silicotic changes during water drilling in the Bulgarian mines.

\section{MATERIALS AND METHODS}

A retrospective and a cross-sectional study using a linear regression analysis for DFP (in cases of silicosis) and nonparametric analysis for the mean value of LP (in cases of asbestosis) were performed.

DFP was studied among 481 quartz exposed exminers, and LP - among the 120 workers exposed to asbestos in the past. 
In 2003, a cross-section study of the average duration of quartz exposure was also carried out until the appearance of initial small round silicotic opacities amongst 480 underground miners (116 - from Bobov Dol, 113 - Balkan 2000, 53 - Antra and 198 by Lucky, Gorubso).

For all quartz-exposed workers we have performed chest radiographies with reading of the pulmonary radiographic silicotic finds using the ILO Classification of radiographs of pneumoconiosis, Geneva 1980. Oneway ANOVA test was applied. SPSS software package was used for statistical processing.

\section{RESULTS AND DISCUSSION}

In order to predict the silicosis development, a retrospective analysis for the role of major risk parameters that affect the appearance of late forms of silicosis was performed.

A calculation of the DFP $=\mathrm{Y}$ (period from the initial quartz exposure up to the appearance of silicosis among underground workers in different mines) was done. Multifactorial regression analysis was used. The regression equation of the statistical multifactorial prognostic model is as follows: $\mathrm{Y}=\mathrm{A}+\mathrm{X} 1 . \mathrm{B}+\mathrm{X} 2 . \mathrm{C}+$ $\mathrm{X}_{3} . \mathrm{D}+\mathrm{X} 4 . \mathrm{E}$ where: $\mathrm{Y}$ is DFP, $\mathrm{A}$ is a free member that adopts different values for corresponding equation, and the coefficients of regression are: B (coefficient for age factor $\mathrm{X}_{1}$ - in years), C (coefficient for factor $\mathrm{X} 2$ - exposure duration during dry drilling - in years), $\mathrm{D}$ (coefficient for $\mathrm{X}_{3}$ - total dust in the work environment air during dry drilling - in $\mathrm{mg} / \mathrm{m} 3$ ), and $\mathrm{E}$ (coefficient for factor $\mathrm{X}_{4}$ - quartz concentration in total dust during dry drilling - in \%).

The coefficients have different values and significance for different mines. By calculating of the average of the DFP (Y), a rough estimate of the morbidity can be done among workers, exposed to quartz in the mines. Analyzing the regression multifactor statistical model, we have established that DFP (Y) duration is influenced by age factor, followed by the exposure duration, the total concentration of the dust in the work environment air during dry drilling, and quartz concentration in the total dust.

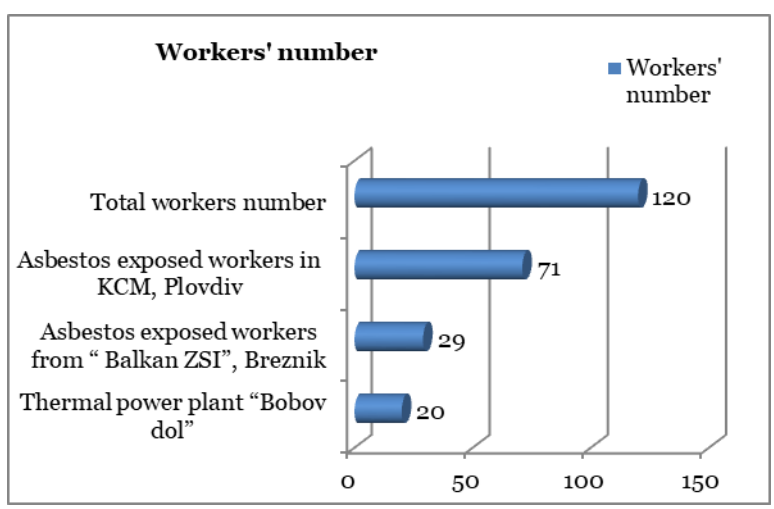

Figure 1. General distribution of asbestos exposed workers

Asbestos exposed workers have had different work places: boiler fitters from Bobov Dol (20 - 15.8\%) with a previous exposure to friction products (e. g. asbestos lining for cars), 29 asbestos exposed workers by Balkan - ZSI, Breznik and 71 former workers exposed to asbestos - from KCM - Plovdiv (Figure 1).

An important premise for assessment of respiratory system status in the studied asbestos exposed workers was the knowledge on the average duration of industrial exposure to asbestos shown in Table 1 . The average duration of asbestos exposure for all exposed workers is $16.5 \pm 7.72$ years.

One worker from "Balkan ZSI", Breznik has had 40 years maximum exposure to asbestos, and one worker had been exposed only one year as an installer in thermal power plant "Bobov Dol" (Table 1).

Table 1. Average duration of asbestos exposure

\begin{tabular}{|l|l|}
\hline Asbestos dust exposure & Duration (in years) \\
\hline $\begin{array}{l}\text { Average duration of } \\
\text { asbestos dust exposure }\end{array}$ & 16.5 \\
\hline Std Deviation & 7.72 \\
\hline Standard Error & 0.70 \\
\hline
\end{tabular}

The latent period (LP) is the time from the initial dust industrial exposure up to the time the disease occurs. LP is an extremely important factor in the assessing of the possibility for late appearance of the dust diseases (for e.g. benign asbestos pleural diseases, malignant pleural mesothelioma, asbestos or quartz related lung cancer, and mixed pneumoconiosis, caused by dust containing asbestos). The distribution of the LP amongst the workers, exposed to asbestos in different productions has shown on Table 2.

Table 2. Distribution of the workers, exposed asbestos in different productions by length of latent period

\begin{tabular}{|c|c|c|c|c|}
\hline $\begin{array}{c}\text { Latent } \\
\text { Period } \\
\text { Duration } \\
\text { (in years) }\end{array}$ & $\begin{array}{c}\text { Asbestos } \\
\text { exposed } \\
\text { workers } \\
\text { from } \\
\text { "Bobov } \\
\text { Dol" } \\
\text { (number } \\
\& \% \text { ) }\end{array}$ & $\begin{array}{c}\text { Asbestos } \\
\text { exposed } \\
\text { workers } \\
\text { from } \\
\text { Balkan } \\
\text { ZSI } \\
\text { (number } \\
\& \% \text { ) }\end{array}$ & $\begin{array}{c}\text { Asbestos } \\
\text { exposed } \\
\text { workers } \\
\text { from } \\
\text { KCM } \\
\text { "Plovdiv" } \\
\text { (number } \\
\& \% \text { ) }\end{array}$ & $\begin{array}{c}\text { Total } \\
\text { number } \\
\text { of } \\
\text { asbestos } \\
\text { exposed } \\
\text { workers } \\
\text { (number } \\
\& \% \text { ) }\end{array}$ \\
\hline Up to 10 yrs & $5(25.0)$ & $5(17.2)$ & $9(12.7)$ & $19(15.8)$ \\
\hline $\begin{array}{l}\text { From } 11 \text { up } \\
\text { to } 15 \text { yrs }\end{array}$ & $6(30.0)$ & $7(24.1)$ & $25(35.2)$ & $38(31.7)$ \\
\hline Above 15 yrs & $9(45.0)$ & $17(58.7)$ & $37(52.1)$ & $63(52.5)$ \\
\hline Total & $\begin{array}{c}20 \\
(100.0)\end{array}$ & $\begin{array}{c}29 \\
(100.0)\end{array}$ & 71 (100.0) & $\begin{array}{c}120 \\
(100.0)\end{array}$ \\
\hline
\end{tabular}

LP up to 10 years has found among 5 (25.0\%) workers from boiler equipment in Bobov Dol, 5 (17.2\%) persons - from Balkan - Breznik and 9 (12.7\%) workers - from KCM Plovdiv. With latency period of 11 to 15 years have been $6(30.0 \%)$ workers from Bobov Dol thermal power station, $7(24.1 \%)$ - workers - from Breznik and 25 (35.2\%) - from KCM, Plovdiv. A longest latent period (over 15 years) was found amongst 9.0 (45.0\%) workers from boiler equipment in Bobov Dol Power Station, 17 (58.7\%) workers from Breznik, and 37 (52.1\%) asbestos exposed workers in KCM, Plovdiv.

Total, among asbestos exposed workers has dominated the LP with 15 years duration followed by LP 11-15 years, and the smallest number were the workers with LP up to 10 years duration (Table 2). The average 
E. Petrova, Appearance of silicosis and asbestosis in dust exposed workers, RAD Conf. Proc., vol. 4, 2020, 118-120

duration of LP among workers from different industries has presented in Table 3 .

Table 3. Mean value of duration of latent period (lp) in workers exposed to asbestos in all productions

\begin{tabular}{|l|l|}
\hline $\begin{array}{l}\text { Total number of the workers exposed to } \\
\text { asbestos }\end{array}$ & 120 workers \\
\hline $\begin{array}{l}\text { Mean value of the LP among workers } \\
\text { exposed to asbestos }\end{array}$ & 17.45 years \\
\hline Std Deviation & 8.45 \\
\hline
\end{tabular}

The mean of the LP for all asbestos exposed workers is $17.45 \pm 8.45$ years.

The influence on the appearance of the po/1, 1/o, 1/1 small round opacities on chest radiography from the average duration of quartz exposure is graphically illustrated in Fig. 2.

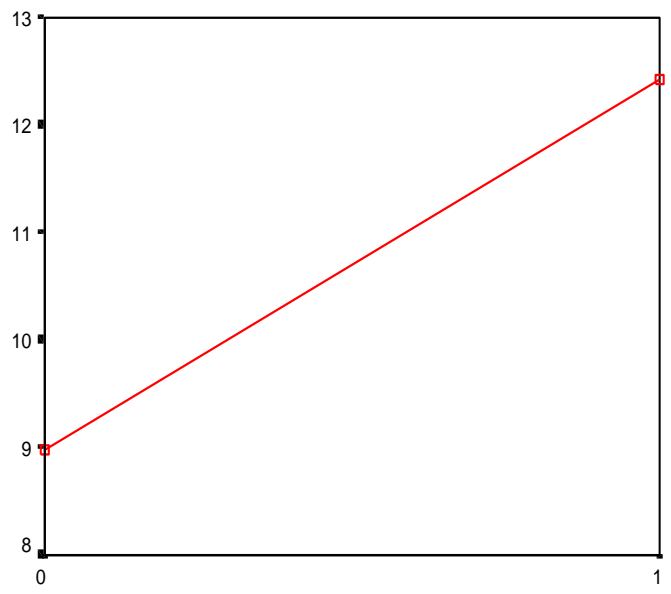

p_gr1

Oneway ANOVA $[\mathrm{p}<0.0001]$

Figure 2. Mean value of quartz exposure and a moment of the appearance of the initial $\mathrm{p}$ small round silicotic shadows of category po/1, p1/o, p1/1

The initial silicotic small round shadows on conventional chest radiography have been found after 12.42 years average exposure to quartz. This trend was statistically significant and has been calculated by Oneway ANOVA $(\mathrm{p}<0.0001)$.

\section{CONCLUSION}

1. The regression equation establishes that the expected duration of DFP up to the silicosis appearance among miners from lead-zinc ore mining averages 13.1 years, and DFP in the uranium mining averages 15.1 years.

2. On the basis of such statistical models, it is possible to calculate the DFP for late forms of silicosis and silicotuberculosis in different mines, and to estimate the moment of the appearance of silicosis.
3. Late forms of silicosis resulting from dry or dry + water drillings in the underground mines are estimated to have been depleted around and after 2000, due to the depletion

4. The minimum quartz exposure up to appearance of initial forms of silicosis was 12.42 year during water drilling in underground Bulgarian mines.

5. The average duration of the LP in the ex-asbestos workers surveyed in the different productions was $17.45 \pm 8.45$ years.

6. Future studies on the silicosis among underground miners working in conditions of water drilling, as well as of overground worker, exposed to dust have to be performed.

\section{REFERENCES}

1. Early Detection of Occupational Diseases, Id. 924154211X, WHO, Geneva, Switzerland, 1986. Retrieved from:

http://apps.who.int/iris/bitstream/handle/10665/3791 2/924154211X.pdf?sequence $=1 \& \mathrm{i}$ Retrieved on: Aug. 15, 2018

2. Е. Петрова, "Късни форми на силикоза и силикотуберкулоза,” Канд. дисертация, Медицински Университет, София, 1988.

(E. Petrova, "Late forms of silicosis and silicotuberculosis," Ph.D. dissertation, Medical University, Sofia, 1988).

3. Е. Петрова, “Силикоза и силикотуберкулоза”, Мед. u физк., C, 1993.

(E. Petrova, Silicosis and silicotuberculosis", Med. and Physc., S, 1993).

4. E. Petrova, "Present-day Characterization of Silicosis in Bulgaria," Revja rada, Varedno izdanje, pp. 131 - 135, 1989.

5. Т. Бурилков, М. Добрева, С. Иванова-Джубрилова, “Минерални прахове в работната среда," Мед. u физк., C, 1983.

(T. Bourilkov, M. Ivanova-Djubrilova, "Mineral Dust in Working Environmental Air," Med. and Physc., S, 1983).

6. "Asbestos, asbestosis, and cancer: The Helsinki criteria for diagnosis and attribution," Scand. J. Work. Environ. Health, vol. 23, no. 4, pp. 311-316, Aug. 1997. PMid: 9322824

7. M. Kidu, T. Tsuda, "Pulmonary Fibrosis Due to Inhaled Inorganic Dusts," in: Basic and Clinical Aspects of Pulmonary Fibrosis, London/Tokyo, UK/Japan, CRC Press, 1994, ch. 28, pp. 389-399.

8. D. Sherson, "Silicosis in the twenty first century," Occup Environ. Med., vol. 59, no. 11, pp. 721 - 722, Nov. 2002. https://doi.org/10.1136/oem.59.11.721 PMid: 12409528 PMCid: PMC174024

9. NIOSH Hazard Review: Health Effects of Occupational Exposure to Respirable Crystalline Silica, DHHS (NIOSH) Publication No. 2002-129, NIOSH, Cincinnati $(\mathrm{OH}), \mathrm{USA}, 2002$

Retrieved from:

https://www.cdc.gov/niosh/docs/2002$129 / \mathrm{pdfs} / 2002$

129.pdf?id=10.26616/NIOSHPUB2002129

Retrieved on: Aug. 15, 2018 